UDC 636.2.083.3(497.11)

$637.5^{\prime} 62.05(497.11)$

COBISS.SR-ID 253146124

Original research paper

Acta Agriculturae Serbica, Vol. XXII, 44 (2017); 147-156

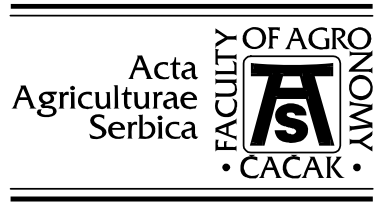

\title{
Analysis of the quality of carcasses of young simental bulls acording to EU standard
}

\section{Miloš ŽI. Petrović ${ }^{1 *}$, Radojica D. Đoković ${ }^{1}$, Marko R. Cincović ${ }^{2}$, Zoran Ž. Ilić ${ }^{3}$, Milun D. Petrović ${ }^{1}$, Vladimir Dosković ${ }^{1}$, Neđeljko R. Karabasil $^{4}$}

${ }^{1}$ University of Kragujevac, Faculty of Agronomy in Čačak, Cara Dušana 34, Čačak, Republic of Serbia

${ }^{2}$ Univesity of Novi Sad, Faculty of Agriculture, Trg Dositeja Obradovića 8, 21000 Novi Sad, Republic of Serbia

${ }^{3}$ University of Priština, Faculty of Agriculture Lešak, 38219 Lešak, Republic of

Serbia

${ }^{4}$ Univesity of Belgrade, Faculty of Veterinary Medicine, Bulevar oslobođenja 18, 11000 Belgrade, Republic of Serbia

Corresponding author: petrovic.milos87@kg.ac.rs

\begin{abstract}
Domestic spotted cattle of Simmental breed with a combined production capacity is mostly grown in the Republic of Serbia. Considering the Serbias potential and tradition in production of quality beef meat as food for human consumption and raw material in the food industry and the demand of the EU market, imposes the need for changing the present and adopting new regulations. The quality of the slaughtered animals is a subject of interest, of both primary production and meat industry. Procedure of classification of carcasses is performed in slaughterhouses immediately after a veterinary examination and measurement of carcasses weight. This paper examines the quality of young cattle carcasses in a slaughterhouse in the Raska district, according to the standard applied in the EU but not in Republic of Serbia. Examination has been conducted on 80 cattle carcasses (young bulls) weighing $450-550 \mathrm{~kg}$. For the quality evaluation and grading of meat the following parameters according to the European
\end{abstract}

Received 18 October 2017 Accepted 30 October 2017 
standard for the classification of cattle carcasses (SEUROP) were used: weight of the animal, the category of a slaughtered animal according to the age and physiological state, slaughter weight / carcass weight and randman, i.e. the conformation of the carcass, development of the muscles of the carcass as well as the development of basic parts (leg, back and shoulder) and the degree of carcass fat tissue coverage.

Key words: quality, carcass, young bulls.

\section{Introduction}

The quality of the slaughtered animals is a subject of interest, of both primary production and meat industry. In order to receive financial reimbursement for adequate output producer must be aware of optimal time for slaughter. Market demand should not dictate the moment of slaughter, producer must know how long a turnus lasts and which investment can achieve good results.

Global population qrowth increases the food demand, therefore according to FAO data (Food Outlook, Biannual Report on Global Food Markets 2016), 320.7 milion tons of meat were produced world wide in 2016. Humans consume meat of different animal species: mammals, birds, fish, amphibians, and mollusks. Most often cattle, pigs and sheep are slaughtered but it is not uncommon to slaughter goats, horses, deer, reindeer, buffalo, yak, camel, llama and others. Poultry and fish are an important source of meat and play an important role in human nutrition since ancient times, but lately rabbit meat is increasingly used. In certain regions of geographically limited belt the meat of the polar bear, seals, antelope, hippopotamus, kangaroo, etc. is being consumed (Rede, 1997).

Animals are allocated into categories based on age, gender, physiological status and into classes according to the quality, i.e. the proportion of meat quantity of the carcass. Procedure of classification of carcasses is performed in slaughter houses immediately after a veterinary examination and measurement of carcasses weight. Food business operator needs to ensure the traceability and the connection in identification of the carcass halves or a quarters with an animal the mentioned parts are obtained from (e.g. ear tag). Staff (classifiers) conducting carcass evaluation should be trained for these tasks. Classifier must be of a minimum secondary veterinary or agronomy education.

Classification of animals starts from species: cattle, pigs, sheep, goats, etc. (Stamenković, Radovanović, 2004). All sorts of domestic animals have incurred through the process of domestication of wild ancestors, most of which still exist today. Slaughtering the animals of certain sort, obtains meat originating from that sort: cattle meat, pig meat, sheep meat. If one considers the category the animals belong to when slaughtered, one gets meat that belongs to certain category (calves meat, beef cattle meat, cattle meat).

According to the Rulebook on the meat quality of the slaughter animal, poultry and game (Official Gazette of SFRJ 34/74, 26/75, 13/78), carcasses or half-carcasses in Serbia are classified into categories according to age into three 
age groups: (1) calves (age in both sexes up to 6 months); (2) cattle (bulls the age of 6 to 18 months; female and castrated males between the ages of six to 30 months); (3) bovine (bull the age over 18 months; female and castrated males over the age of 30 months). Within each of mentioned age categories carcasses are being classified according to following criteria: (1) the mass of the trunk (or mass of the two halves); (2) the conformation of the carcass; (3) fat tissue coverage and meat marbling of carcass; (4) the color of muscle and fat; (5) texture and consistency of muscle and fat tissue.

Carcass weight includes processed carcass without internal organs (with the exception of the kidneys and renal adipose tissue), skin, head, lower parts of legs (separated in the lower part of the carpal, tarsal joints is measured respectively), large blood vessels, spinal cord and the genital organs. Carcass halves represent the slit hull along the line of separation, through the center of the vertebrae, pelvic and thorax. Quarters are obtained by cutting of carcasses, cut that goes between the 12 th and 13th rib and over the bodies of 12 dorsal vertebrae. It should be noted that the cold carcass weights to about $2 \%$ less than the mass of warm carcass.

Favorable (excellent) conformation of carcass means that all the profiles are extremely well developed and convex. Legs of fleshy carcasses have a convex profile, the back sides are very well developed and diverse and the blades are filled and well-formed. Weak or unfavorable conformation of the carcass is characterized by profiles which are concave, leg is poorly developed, the back is narrow, the blades are straight and are conspicuous protruding bones.

From the aspect of quality, preferred coverage is the case when carcass or halves have uniformly and evenly distributed, continuous, but not too thick layer of fat tissue.

Following parameters for classifying carcasses of cattle are used in the EU (EC No 1234/2007): carcass weight, the category of a slaughtered animal according to the age and physiological state, the class based on the conformation i. e. development of the muscles of the carcass or halves as well as the development of basic parts (leg, back and shoulder blade), the degree of fat tissue coverage and others. The carcasses or half-carcasses are classified into categories on the basis of age and physiological status of the animals: calves (up to eight months of age), old calves (from eight to 12 months of age), heifers (female animals which have not calved), young bulls (up to 24 months of age), bulls (older than 24 months), castrated male animals and cows (female animals that have calved).

On the basis of the conformation image 1, carcasses are classified into one of six classes, according to the system which is represented in the EU.

Carcass fat tissue coverage (image 2) is assessed by ranging from 1 (very poor surface coverage) to 5 (very strong coverage). 


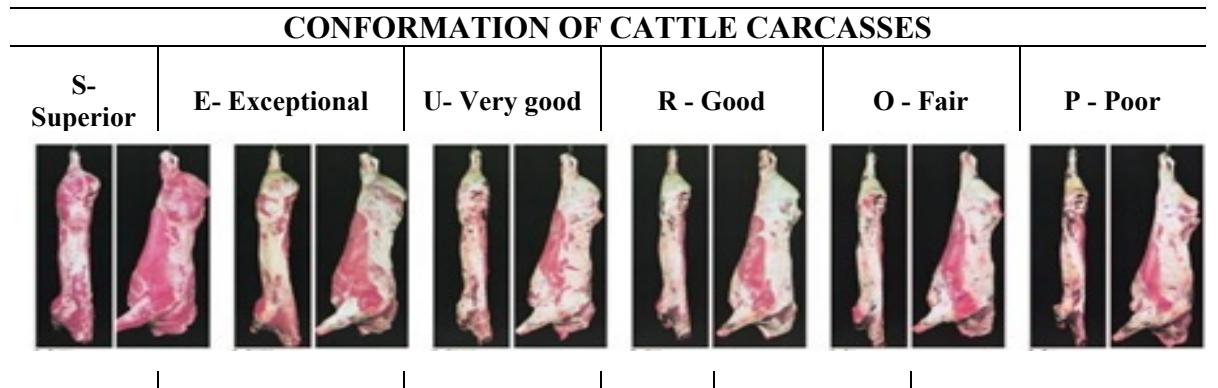

Image 1. Carcass of adult cattle and grading (SEUROP) in EU countries (Council Regulation (EC) No 1234/2007, Commission Regulation (EC) No 1249/2008; Commission European, Directorate-General for Agriculture and Rural Development)

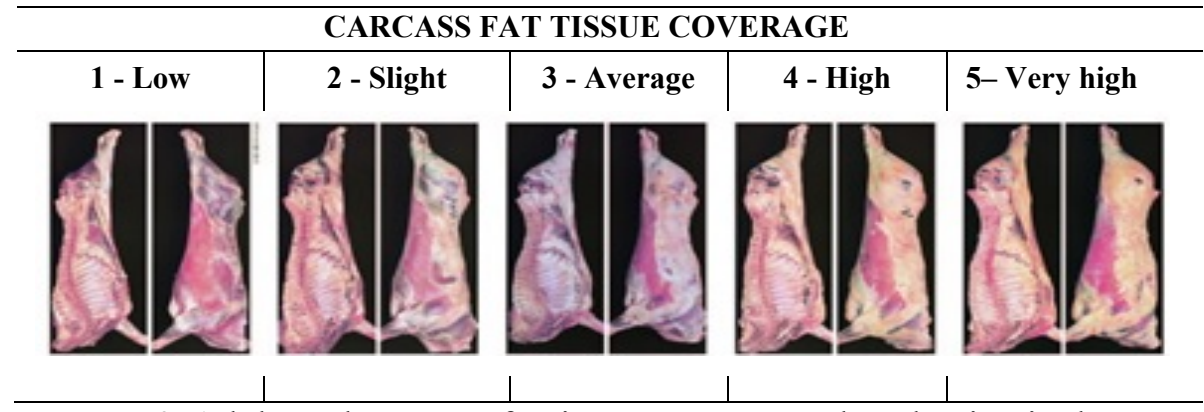

Image 2. Adult cattle carcass fat tissue coverage and evaluation in the EU countries (Council Regulation (EC) No 1234/2007, Commission Regulation (EC) No 1249/2008; Commission European, Directorate-General for Agriculture and Rural Development)

The aim of this paper was to investigate the quality of slaughtered beef cattle (bulls) in a slaughterhouse, following the appropriate criteria. In achieving that, tasks are set to examine the quality of beef cattle (bulls) by monitoring the following parameters: the weight of live animals, slaughter carcass weight, randman, correctness of slaughter processing, the carcass class based on conformation, degree of fat tissue cover.

\section{Materials and methods}

Throughout 13 sampling examination has included 80 carcass of domestic Simmental beef cattle (young bulls), whose body weight was $450-550 \mathrm{~kg}$. 
Measuring the animal weight immediately after the arrival to the slaughterhouse and prior to slaughter is carried out on the scale with accuracy of $\pm 0.5 \mathrm{~kg}$. Measuring the mass of the carcass at least 45 minutes after the slaughter was carried out on the scale with accuracy of $\pm 0.5 \mathrm{~kg}$.

At the end of processing line correctness score was performed: carcass without internal organs (except kidneys), skin, head, lower parts of the legs (separate in the lower carpal or tarsal joint), large blood vessels, spinal cord and the genital organs.

Carcass conformation rate (class $\mathrm{S}, \mathrm{E}, \mathrm{U}, \mathrm{R}, \mathrm{O}$ and $\mathrm{P}$ ) and the fat tissue coverage (score 1, 2, 3, 4 and 5) was determined within 45 minutes after slaughter, according to criteria used in the European Union.

After data collection, statistical analysis of the tested values was started. Statistical analysis was performed in a statistical package StatsSoft INC (Statistica for Windows 6.0 computer program version manual Tulsa, StatSoft Inc., 1995).

\section{Results and discussion}

Sampling included cattle (young bulls) from purchase, aged about one year. All trunk had adequate slaughter processing.

Similar results were obtained by Petrović et al. (2016) who have examined the influence of the final mass of young Simmental bulls on randman. The study was conducted on 54 young bulls carcasses, which were divided into two groups. The first group consisted of bulls which final body weight is $450-500 \mathrm{~kg}$, and the second group refers to $550-600 \mathrm{~kg}$. Their results show that the average weight of the first group of cattle was $478.40 \mathrm{~kg}$, the second group $569.42 \mathrm{~kg}$, while the average slaughter weight of the trunk of the first group was $250.4 \mathrm{~kg}$ and $298.3 \mathrm{~kg}$ of another group. Average slaughtering percentage was $51.87 \% \pm 2.38$ (total for the group 1 and group 2), and ranged from $42.00 \%$ to $57.00 \%$.

According to research of Aleksić et al. (2002) the mean value of the test results of the slaughter male cattle Domestic Simmental (DSG) and crossbreeds domestic Simmental and Limousine (MDL) was successively: weight of the animals prior to slaughter $592.7 \mathrm{~kg}$ (DSG) and $589.8 \mathrm{~kg}$ (MDL); hot halfcarcasses with lard $329.9 \mathrm{~kg}$ (DSG) and $352.7 \mathrm{~kg}$ (MDL); dressing percentage $55.66 \%$ (DSG) and 59.79\% (MLD). Based on the results the authors conclude that domestic Simmental cattle crossed with limousine breed achieved higher dressing percentage of $4.55 \%$ as compared to young cattle of domestic Simmental breed.

Class of the carcass based on the conformation was evaluated as $\mathrm{O}$ at $77.5 \%$ of the cases and as $\mathrm{R}$ at $22.5 \%$ of the cases. The carcass fat tissue coverage degree was rated to be 3 at $88.75 \%$ and 4 at $11.25 \%$ of carcasses. Similar results were obtained by Petrović et al. (2017), who were analyzed the degree of coverage of young bull's carcasses with fat tissue according to EU standard. The 
study was conducted on 123 young bull's carcasses. Their results show that three categories have been established in terms of the degree of fat cover $(2,3,4)$. Only one carcasses was of the category 2 . The 3 . category was found at 107 carcasses, which is significantly more than in the category 2 and in category 4 (15 trunks).

Table 1 show the cumulative average value of live animals mass, slaughter weight and slaughter randman of all 80 cattle carcasses which have been subject to evaluation. The average weight of live animals was $497.74 \pm 29.0 \mathrm{~kg}$ with a coefficient of variation of $5.83 \%$. The mean value of the carcass slaughter weight was $265.10 \pm 19.6 \mathrm{~kg}$, and the coefficient of variation was $7.4 \%$.

Analyzing the randman of cattle the average percentage of $52.74 \%$ was established, with minimum/maximum interval from 42.00 to $59.00 \%$.

Table 1. Summary review of the average value of live animals mass, slaughter weight and randman

\begin{tabular}{|r|c|c|c|}
\hline \multicolumn{1}{|c|}{ Parameter } & $\begin{array}{c}\text { Live animals } \\
\text { mass (kg) }\end{array}$ & $\begin{array}{c}\text { Slaughter } \\
\text { weight of } \\
\text { carcass (kg) }\end{array}$ & $\begin{array}{c}\text { Randman } \\
\mathbf{( \% )}\end{array}$ \\
\hline Number of carcasses & \multicolumn{3}{|c|}{80} \\
\hline Mean value & 497.74 & 265.10 & 52.74 \\
\hline Standard deviation & 29.00 & 19.60 & - \\
\hline Standard error & 3.250 & 2.20 & - \\
\hline Minimum & 412.00 & 206.00 & 42.00 \\
\hline Maximum & 548.00 & 302.00 & 59.00 \\
\hline $\begin{array}{r}\text { Coefficient of } \\
\text { variation (\%) }\end{array}$ & 5.83 & 7.40 & - \\
\hline
\end{tabular}

Figure 1 show the results of the percentage findings of class/conformation of trunks and the degree of carcass fat tissue coverage (figure 2) in all the examined carcasses of young bulls $(n=80)$.

For all of the carcasses only two categories in terms of class have been set: $\mathrm{O}$ (fair) $(\mathrm{n}=62)$ and $\mathrm{R}($ good $)(\mathrm{n}=18)$.

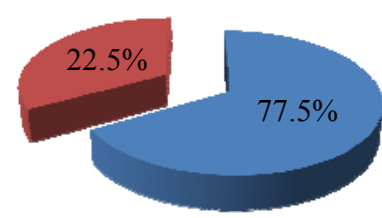

Figure 1. Percentage of carcasses classified as $\mathrm{O}$ and $\mathrm{R}$

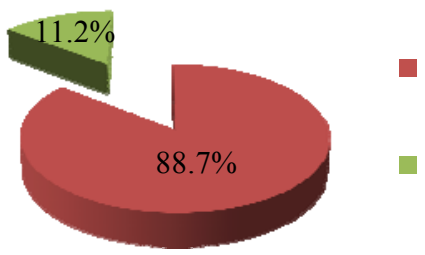

Figure 2. Degree of carcass coverage wit fat tissue 
Regarding fat tissue coverage degree two categories have been determined: 3 (mid coverage) and 4 (high coverage). Significantly more carcasses were labeled as category $3(n=71)$ compared to number of carcasses labeled as category 4 $(\mathrm{n}=9)$.

Considering the quality, beef meat is highly appreciated foodstuff in human nutrition. Production and consumption of beef meat has a negative trend in last several years and holds third position after pork and poultry (Ostojić et al., 2005; Ostojić et al., 2006). Domestic demand for beef meat is partially covered by import, because domestic production is not sufficient. Despite good beef production potential and tradition for export, Serbia fails to use its full export potential towards EU market (Aleksić et al., 2007).

In order to improve the current situation it is necessary to enhance and maintain agro-economic policies and strengthen the primary production. Some possible solutions to improve production and quality are improving the quality of breeding material, nutrition and cultivation technology (Aleksić et al., 2011; Šefer et al., 2015). Development of production, quality and placement of this type of meat requires improvement to the quality of meat in carcasses, which refers to the contribution of edible parts, carcass conformation and the carcass fat coverage, then processing quality and sensory properties (Sretenović et al., 2011; Ostojić-Andrić et al., 2012).

Carcasses meat rating has immeasurable importance as it allows payment based on achieved meat quality and therefore makes stimulus to producers in the primary sector to improve the process of rearing cattle for slaughter. Unfortunately regulations which defining more precisely the quality of meat (Official Gazette of SFRJ 34/74, 26/75, 13/78) are only partialy implemented in Republic of Serbia, because meat is classified based on the age of slaughtered animals, live weight and on the categories of meat (outside the category, I category, II category, III category).

In developed countries, the achieved quality of slaughtered animals and the quality of meat in carcasses is taken into account as basis for payment of slaughtered animals. In EU countries, SEUROP classification system enables prediction of the meat amount in the carcass, which is the basis for determining the selling price of cattle. Member states are obliged to implement the classification in all slaughterhouses that slaughter more than 75 animals a week, at the annual average.

SEUROP evaluating system for carcasses quality is conceptually designed to provide a uniform approach to the assessment of the meat quality. Republic of Serbia is a candidate for EU membership and to achieve that, it will have to implement adopted rules and regulations for quality assessment.

In order to provide uniformity of adult cattle carcasses classification in the EU, parameters and criteria are specifically defined in the regulations as well as the possible deviation from the basic models for their implementation. In this way, the meaning of the following terms is precisely defined: adult cattle, 
presentation angle for classification and category of the carcass, the criteria for scoring conformation and carcass fat tissue coverage's as well the identification of the carcass.

It can be concluded, from the obtained data, that it is necessary to make improvements in the field of primary production and to provide a better meat yield and quality in carcasses.

\section{Conclusion}

Based on the results and their critical considerations the following can be concluded:

- The average weight of live animals ranges between $497.74 \pm 29.0 \mathrm{~kg}$;

- The average slaughter weight of the carcass ranges between $265.10 \pm 19.6 \mathrm{~kg}$;

- The average randman is $52.74 \%$ and it ranged from $42.00 \%$ to $59.00 \%$;

- Class of the carcass based on the conformation was evaluated as $\mathrm{O}$ at $77.5 \%$ of the cases and as $\mathrm{R}$ at $22.5 \%$ of the cases;

- The carcass fat tissue coverage degree was rated to be 3 at $88.75 \%$ and 4 at $11.25 \%$ of carcasses;

- The correctness of slaughter processing is adequate in the slaughterhouse in which the carcass quality assessment was conducted.

\section{Acknowledgments}

This research was supported by the Ministry of Education, Science and Technological Development of the Republic of Serbia, Projects TR 31001.

\section{References}

Aleksić S., Petrović M.M., Pantelić V., Novaković Ž., OstojićAndrić D., Stanišić N., Nikšić D. (2011): Chemical, technological and sensory properties of meat from different cattle genotypes. Biotechnology in Animal Husbandry, 27 (3), book 2: 913-918.

Aleksić S., Miščević B., Petrović M.M., Pavlovski Z., Josipović S., T o mašević D. (2002): Investigation of factors affecting the results regarding the dressing percentage value of male young cattle of domestic Simmental breed and crossbreed of the Simmental and Limousine breed. Biotechnology in Animal Husbandry, 18 (3-4): 9-14.

Aleksić S., Petrović M.M., Sretenović LJ., Pantelić V., Tomašević D., Ostojić-Andrić D. (2007): Cattle production: Current situation and future directions of development in Republic of Serbia. Biotechnology in Animal Husbandry, 23 (5-6-1): 1-10.

Food Outlook biannual report on global food markets October 2016 Food and Agriculture Organization of the United Nations 
Petrović M., Karabasil N., Đoković R., Cincović M., Petrović M.D., Ilić Z., Stanimirović Z. (2016): Influence of the final mass of young bulls of the Simental breed on dresing percentage, „XXI Conference on Biotechnology“"11-12. mart 2016, Faculty of Agronomy in Čačak, Book of proceedings, 21 (24), 577-580.

Ostojić D., Bogdanović V., Petrović M. M., Aleksić S., Miščević B., Pantelić V. (2005): Criteria of consumers when purchasing beef in retail stores, A. Consumer attitude towards beef quality preferences and habits in selection of the category of retail meat parts and giblets. Biotechnology in Animal Husbandry, 21 (5-6), book 2: 263-268.

Ostojić D., Bogdanović V., Petrović M. M., Aleksić S., Miščević B., Pantelić V. (2006): Criteria of Consumers When Purchasing Beef in Retail Stores, Part B: Position of beef compared to other meat types, reasons and frequency of its use in everyday nutrition and preparation methods. Biotechnology in Animal Husbandry, 22 (3-4): 45-53.

Ostojić-Andrić D., Aleksić S., Hristov S., Novaković Z., Petrović M. M., Nikšić D., Stanišić N. (2012): Serbia in the implementation of SEUROP standard for beef carcass clasification legislation, parametars and evaluation criteria. Biotechonology and Animal Husbandry 28 (1): 47-58.

Petrović M., Đoković R., Petrović M.D., Cincović M., Ilić Z., Čobanović N., Karabasil N. (2017): Analysis of the degree covering of young bull carcass with fat tissue according to eu standard. $6^{\text {th }}$ International Symposium on Agricultural Sciences"AgroReS 2017", Banja Luka, Bosnia and Herzegovina. pp 46.

Rulebook on the quality of animals for slaughter, poultry and g a me (Official Gazette of SFRY 34/74, 26/75, 13/78)

Commission Regulation (EC) No 1249/2008 laying down detailed rules on the implementation of the Community scales for the classification of the beef, pig and sheep carcases and the reporting of prices thereof, Official Journal of the European Parliament.

The Council Regulation of the European Union (EC) No $1234 / 2007$, of 22 October 2007 establishing a common organisation of agricultural markets and on specific provisions for certain agricultural products (Single CMO Regulation)

Rudolf R., Petrović. Lj. (1997): Tehnologija mesa i nauka o mesu. Tehnološki fakultet, Novi Sad.

Stamenković T., Radovanović R. (2004): Prilog poznavanju trupova zaklanih goveda, svinja, ovaca i kokoši. Tehnologija mesa (45) 5-6: 219-224.

Sretenović Lj., Pantelić V., Novaković M., Novaković Ž., Ostojić-Andrić D. (2011): Production of beef meat with functional food properties. Biotechnology in Animal Husbandry, 27 (3), book 1: 373-385.

Šefer D., Marković R., Nedeljković-Trailović J., Petrujkić B., Radulović S., Grdović S. (2015): The application of biotechnology in animal nutrition. Veterinarski glasnik, 69 (1-2): 127-137. 


\title{
ANALIZA KVALITETA TRUPOVA MLADIH BIKOVA SIMENTALSKE RASE PREMA EU STANDARDU
}

\author{
M. ŽI. Petrović ${ }^{*}$, R. D. Đoković ${ }^{1}$, M. R. Cincović ${ }^{2}$, Z. Ž. Ilić ${ }^{3}$, M. D. \\ Petrović $^{1}$, Vladimir Dosković ${ }^{1}$, N. R. Karabasil ${ }^{4}$ \\ ${ }^{1}$ Univerzitet u Kragujevcu, Agronomski fakultet u Čačku, Cara Dušana 34, \\ Čačak, Republika Srbija \\ ${ }^{2}$ Univerzitet u Novom Sadu, Poljoprivredni fakultet, Trg Dositeja Obradovića 8, \\ 21000 Novi Sad, Republika Srbija \\ ${ }^{3}$ Univerzitet u Prištini, Poljoprivredni fakultet Lešak, 38219 Lešak, Republika \\ Srbija \\ ${ }^{4}$ Univerzitet u Beogradu, Fakultet veterinarske medicine, Bulevar oslobođenja \\ 18, 11000 Beograd, Republika Srbija
}

\section{Rezime}

Domaće šareno goveče u tipu simentalca je rasa goveda kombinovanih proizvodnih sposobnosti koja se najviše gaji u Republici Srbiji. Posmatrajući potencijal i tradiciju naše zemlje u proizvodnji kvalitetnog goveđeg mesa kao namirnice za ishranu ljudi i sirovine za preradu u prehrambenoj industriji s jedne strane, i potreba tržista EU sa druge strane, nameće se potreba za menjanjem postojećih i donošenjem novih propisa. Kvalitet trupova zaklanih životinja je predmet interesovanja, kako primarne proizvodnje, tako i industrije mesa. Postupak klasiranja trupova odnosno polutki sprovodi se u klanicama neposredno nakon veterinarskog pregleda i utvrđivanja mase trupa. $U$ radu je ispitan kvalitet trupova junadi, zaklanih u jednoj klanici u Raškom okrugu, prema standardu koji se primenjuje u zemljama Evropske Unije a koji se još ne primenjuje u Republici Srbiji. Ispitivanje je sprovedeno na 80 trupova junadi (mladih bikova) telesne mase $450-550 \mathrm{~kg}$. Za procenu kvaliteta i klasiranje mesa u trupovima korišćeni su parametri, prema Evropskom standardu za klasiranje trupova goveda SEUROP: masa životinje, kategorija zaklane životinje shodno starosti i fiziološkom stanju, klanična težina/masa trupa i randman, konformacija trupa tj. razvijenosti mišića trupa kao i razvijenosti osnovnih delova (but, leđa i plećka) i stepen prekrivenosti trupa masnim tkivom.

Ključne reči: kvalitet, trupovi, mladi bikovi 